\title{
14. ORGANIC MATTER AT SITES 642, 643, AND 644, ODP LEG 104
}

\author{
Thomas J. McDonald, ${ }^{2}$ Mahlon C. Kennicutt II, ${ }^{2}$ James M. Brooks, ${ }^{2}$ and Keith A. Kvenvolden ${ }^{3}$
}

\begin{abstract}
Sedimentary extractable organic matter was analyzed at three ODP Leg 104 sites in the Norwegian Sea. Organic carbon content ranged from less than $0.1 \%$ to a maximum of $1.8 \%$. Extractable organic matter content and unresolved complex mixture concentrations were low and randomly distributed. Low levels of aliphatic (branched and normal) and aromatic hydrocarbons were detected in all of the sediments analyzed. Total aliphatic and aromatic hydrocarbon concentrations ranged from 176 to 3,214 and 6 to $820 \mathrm{ppb}$, respectively. The concentrations of individual aliphatic (n- $\mathrm{C}_{15}$ to $\mathrm{n}-\mathrm{C}_{32}$ ) and aromatic (two- to five-ring) hydrocarbons were generally less than $50 \mathrm{ppb}$ and less than $10 \mathrm{ppb}$, respectively. No significant trend with sub-bottom depth was observed in either bulk organic matter or individual hydrocarbon concentrations. The predominant source of Cenozoic sedimentary hydrocarbons is concluded to be ice-rafted debris from the adjacent continent. All sites contain a mixture of recycled, mature petroleum-related and terrestrially derived hydrocarbons.
\end{abstract}

\section{INTRODUCTION}

The ultimate distribution of organic matter in marine sediments is controlled by a number of factors including the amount and composition of the source material, depositional environment, depth of burial, diagenesis, and upward migration of liquids and gases from deeper accumulations (Kennicutt et al., 1987a). All of these factors can potentially influence the organic carbon content, isotopic composition, and molecular compositions of the extractable and residual carbon in sediments. The Vøring Plateau (Fig. 1) lies within a region that has been heavily influenced by glaciers in Plio-Pleistocene time. Ice-rafted material of terrigenous origin has been suggested as a significant source of sedimentary organic matter. Another potential source of organic matter to the sediment in this region is migration from deep petroleum sources, especially in the region of the inner Vøring Plateau (Morris, 1976). Sedimentary organic matter from Ocean Drilling Program (ODP) Leg 104 sites was analyzed in a continuing effort to understand the distribution, origin, and diagenesis of organic matter in oceanic sediments.

\section{EXPERIMENTAL TECHNIQUES}

Aliphatic and polynuclear aromatic hydrocarbon concentrations were analyzed by gas chromatography with flame ionization (GC/FID) and mass spectrometric detection (GC/MS), respectively. The analytical procedure provides quantitative aliphatic and aromatic hydrocarbon concentrations in the $\mathrm{C}_{10}$ to $\mathrm{C}_{15}$ n-alkane range as well as the $\mathrm{C}_{15}{ }^{+}$fraction. Freeze-dried samples were ground and extracted in a Soxhlet apparatus for $12 \mathrm{hr}$ with methylene chloride. Copper turnings were added to the boiling flask to remove elemental sulfur. Internal standards $\mathrm{C}_{10}$ and $\mathrm{C}_{14}$ alkylbenzenes, $\mathrm{d}_{8}$-naphthalene, $\mathrm{d}_{10}$-phenanthrene, $d_{10}$-acenaphthene, $d_{12}$-chrysene, and $d_{12}$-perylene were added to the sediment prior to extraction. The deuterated aromatic compounds were used to correct for losses of analytes during analysis by GC/MS. The alkylbenzenes were used in a similiar fashion to quantify aliphatic hydrocarbon concentrations by GC/ FID. Hexamethylbenzene was added just prior to GC/FID or

\footnotetext{
${ }^{1}$ Eldholm, O., Thiede, J., Taylor, E., et al., 1989. Proc. ODP, Sci. Results, 104: College Station, TX (Ocean Drilling Program).

2 Dept. of Oceanography, Texas A\&M University, College Station, TX 77843.

3 U.S. Geological Survey, Menlo Park, CA 94025.
}

GC/MS analysis to calculate absolute analyte recoveries. All cleaning procedures, contamination control, system blanks, spiked blanks, and standards (internal and external) conform to the NOAA Status and Trends Program described in detail elsewhere (Kennicutt et al., 1987a; MacLeod et al., 1985). Sample components were separated using a $50-\mathrm{m} \times 0.32-\mathrm{mm}$ I.D. (0.52$\mu \mathrm{m}$ film thickness) fused silica capillary column coated with a cross-linked methyl silicone liquid phase. Typical GC/MS and GC/FID operating conditions are presented in Tables 1 and 2 .

A carbon preference index (CPI) was determined as the ratio of odd-numbered normal alkanes with 23 to 31 carbons, to the even-numbered normal alkanes with 24 to 32 carbons. The unresolved complex mixture (UCM) is defined as the rise above the instrumental baseline of the FID response under the given operating conditions. The UCM concentration was semiquantitatively determined using the FID response for a normal alkane eluting in the same gas chromatographic regions as the UCM. Extractable organic matter (EOM) concentrations were determined gravimetrically with a Cahn electrobalance.

\section{RESULTS AND DISCUSSION}

All data are summarized in the Appendix with selected subsets of data presented in a graphical form for discussion. The ranges and averages for various organic matter parameters are also summarized in Table 3 .

\section{Site 642-Outer Voring Plateau}

Site 642 , on the outer Vøring Plateau, is 1272 meters below sea level (mbsl) (Fig. 1). The $320 \mathrm{~m}$ of cored sediment are predominantly pelagic-hemipelagic of Neogene and Quaternary ages, with approximately 50 interbedded ash layers (Eldholm, Thiede, Taylor, et al., 1987). Total organic carbon (TOC) at Site 642 averages $0.9 \%$ and ranges from $0.3 \%$ to $1.5 \%$ (Fig. 2, Table 3). This is similar to TOC's measured by Hood et al. (1976) and Erdman and Schorno (1976) in the same area. The highest values are present in Miocene sediments (164 m to $193 \mathrm{~m}$ sub-bottom) where sedimentation rates were estimated to be $1.7 \mathrm{~cm} /$ 1000 yr. Abundant silicious components in this time period (middle Miocene) suggest enhanced marine productivity. Rock-Eval analysis confirms the presence of a mixture of marine and terrestrial organic matter at this site (kerogen Type II-III, Kvenvolden and McDonald, this volume).

Extractable organic matter (EOM) content ranges from 11 ppm to $18 \mathrm{ppm}$, with an average of $12 \mathrm{ppm}(\mathrm{n}=6$, Fig. 2 , Table 


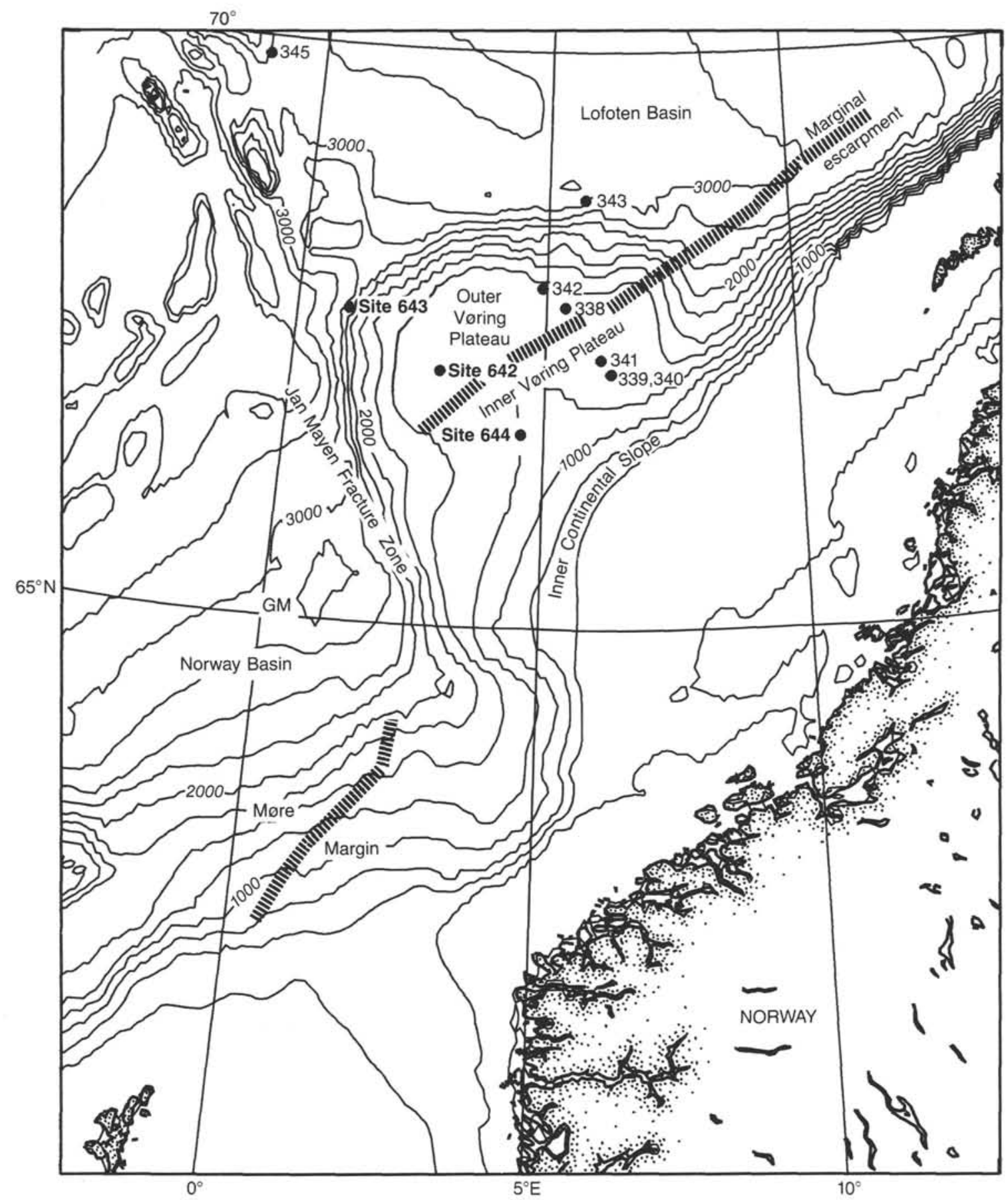

Figure 1. Vøring Plateau coring sites, ODP Leg 104. Contours in meters.

3). The unresolved complex mixture (UCM) varies from 8 to 13 ppm (Fig. 2, Table 3). Individual alkane concentrations vary from $<5$ to $371 \mathrm{ppb}$ but are in general less than $50 \mathrm{ppb}$ (Fig. 3, Appendix). Total n-alkane concentrations (sum of $\mathrm{C}_{15}$ to $\mathrm{C}_{32}$ normal alkanes) are low ranging from 239 to $1,478 \mathrm{ppb}$ (Fig. 4). The carbon preference index ranges from 2.4 to 7.6 indicating a significant presence of odd-number chain length normal alkanes previously attributed to terrestrially sourced organic matter (Fig. 4; Kennicutt et al., 1987b). The aliphatic hydrocarbons represent a mixture of terrestrial and mature, petrogenic inputs with a small contribution from marine sources possible. Pristane and phytane are present in nearly equal amounts except in the shallowest and deepest sections (Fig. 4). No trend in aliphatic hydrocarbon concentrations with increasing depth is ob- served (Figs. 3 and 4). Polynuclear aromatic hydrocarbons (PAH) are also present at low concentrations and range from $24 \mathrm{ppb}$ to $126 \mathrm{ppb}$ (sum of the PAH's listed in the Appendix) and also show no apparent trend with depth (Figs. 5 and 6). With few exceptions individual $\mathrm{PAH}$ concentrations are less than $10 \mathrm{ppb}$ (Fig. 3, Table 3). Based on the low concentrations of hydrocarbons detected, a lack of an increase with increasing depth, and supporting geological and stratigraphic data, we believe the majority of the hydrocarbons at Site 642 are derived from organic matter that was ice-rafted to its present location.

\section{Site 643-Outer Voring Plateau}

ODP Site 643 is located on the lower slope near the foot of the outer Vøring Plateau at $2753 \mathrm{mbsl}$. Drilling penetrated 
Table 1. Operating conditions for the analysis of polynuclear aromatic hydrocarbons by gas chromatography/ mas spectrometry.

Mass Spectrometer-GC/MS HP 5996 linked with an
HP1000 (RPN) Data System
or
- GC/MSD HP 5970 Mass Selective
Detector interfaced to an HP 5970 Gas
Chromatograph configures to an HP
7946 computer linked with HP1000
(RPN) Data System

$\begin{array}{ll}\text { Ion source: } 250^{\circ} \mathrm{C} & \text { Multiplier voltage: } 2500 \mathrm{~V} \\ \text { Transfer line: } 290^{\circ} \mathrm{C} & \text { Entrance lens: } 50 \mathrm{mVV} / \mathrm{AMU} \\ \text { Analyzer: } 250^{\circ} \mathrm{C} & \text { Repeller: } 9.8 \mathrm{~V} \\ \text { Run time: } 36 \mathrm{~min} & \text { Ion focus: } 16 \mathrm{~V} \\ \text { Scan start time: } 5 \mathrm{~min} & \text { Axis gain: }-63 \\ \text { Electron energy: } 70 \mathrm{eV} & \text { Axis offset: }-6 \\ \text { X-ray: } 44 \mathrm{~V} & \text { AMU gain: } 149\end{array}$

Selected lon Monitoring

\begin{tabular}{|c|c|c|}
\hline$M / Z$ & Dwell Time (ms) & Compounds Detected \\
\hline 91 & 30 & *alkylbenzenes \\
\hline 128 & 30 & naphthalene \\
\hline 136 & 30 & ${ }^{*} \mathrm{~d}_{8}$-naphthalene \\
\hline 142 & 30 & $\mathrm{C}_{1}$-naphthalenes \\
\hline 154 & 30 & biphenyl, acenaphthene \\
\hline 156 & 30 & $\mathrm{C}_{2}$-naphthalenes \\
\hline 162 & 30 & *hexamethylbenzene \\
\hline 164 & 30 & $* d_{10}$-acenaphthene \\
\hline 166 & 30 & fluorene \\
\hline 178 & 30 & phenanthrene/anthracene \\
\hline 188 & 50 & $* \mathrm{~d}_{10}$-phenanthrene \\
\hline 192 & 50 & $C_{1}-3$ rings \\
\hline 202 & 50 & fluoranthene, pyrene \\
\hline 228 & 100 & benz(a)anthracene, chrysene \\
\hline 240 & 100 & ${ }^{*} d_{12}$-chrysene \\
\hline 252 & 100 & benzopyrenes, perylene \\
\hline 264 & 150 & ${ }^{*} d_{12}$-perylene \\
\hline 278 & 150 & dibenzanthracenes \\
\hline
\end{tabular}

Gas Chromatography

Injector: $300^{\circ} \mathrm{C}$, splitless mode

Total Run Time: $36 \mathrm{~min}$

Column: $50 \mathrm{~m}, 0.52-\mu \mathrm{m}$ film, $0.31-\mathrm{mm}$ i.d., cross-linked methyl silicone (HP)

$\begin{array}{ll} & \frac{\text { Level 1 }}{\text { Temp 1 }} \\ \text { Time 1 } & 00^{\circ} \mathrm{C} \\ \text { Rate } & 10^{\circ} \mathrm{C} / \mathrm{min} \\ \text { Temp 2 } & 300^{\circ} \mathrm{C} \\ \text { Time 2 } & 10 \mathrm{~min}\end{array}$

*Internal standards.

$565 \mathrm{~m}$ of pelagic and hemipelagic Cenozoic sedimentary sequences. Total organic carbon ranges from $<0.1 \%$ to $1.8 \%$ (Fig. 2). Organic carbon concentrations increase irregularly with depth, reaching a maximum value in the Oligocene ( $347 \mathrm{mbsf}$ ) of $1.8 \%$ (Fig. 2). Underlying Eocene sediments have low organic carbon concentrations, averaging less than $0.1 \%$. RockEval analyses suggest that the organic matter at this site is a mixture of Types II and III (Kvenvolden and McDonald, this volume). EOM concentrations range from $6 \mathrm{ppm}$ to $22 \mathrm{ppm}$ and average $11 \mathrm{ppm}(\mathrm{n}=16$, Fig. 2, Table 3$)$. UCM concentrations range from $5 \mathrm{ppm}$ to $17 \mathrm{ppm}$ (Fig. 2). As at Site 642, total n-alkane concentrations were low and ranged from 176 to $1,196 \mathrm{ppb}$ with individual compound concentrations generally less than 50 ppb (Fig. 3 and 4). The CPI varies from 1.0 to 5.3 and pristane/ phytane ratios vary from 0.6 to 3.9 (Fig. 4 and Appendix). PAH concentrations are also similiar to those at Site 642 with total PAH ranging from $6 \mathrm{ppb}$ to $95 \mathrm{ppb}$ (Figs. 5 and 6, Table 3). As at Site 642 , no regular trends with depth are apparent and an ice-rafted mechanism of transport is suggested as the predominant source of hydrocarbons and organic matter at Site 643.
Table 2. Operating conditions for the analysis of aliphatic hydrocarbons by gas chromatography with flame ionization detection.

\begin{tabular}{|c|c|c|}
\hline \multicolumn{3}{|c|}{ Gas Chromatographs: } \\
\hline \multicolumn{3}{|c|}{ Hewlett-Packard 5880} \\
\hline & $\begin{array}{l}\text { Temp. } 1 \\
\text { Time 1 } \\
\text { Rate } \\
\text { Temp. } 2 \\
\text { Time 2 }\end{array}$ & $\begin{array}{l}60^{\circ} \mathrm{C} \\
0 \mathrm{~min} \\
12^{\circ} \mathrm{C} / \mathrm{min} \\
300^{\circ} \mathrm{C} \\
9 \mathrm{~min}\end{array}$ \\
\hline & $\begin{array}{l}\text { FID Temp. } \\
\text { Inj. Port } \\
\text { Carrier Gas } \\
\text { Make Up Gas } \\
\text { Splitless mode }\end{array}$ & $\begin{array}{l}300^{\circ} \mathrm{C} \\
300^{\circ} \mathrm{C} \\
\text { Helium } \\
\text { Helium }\end{array}$ \\
\hline Column: & \multicolumn{2}{|c|}{$\begin{array}{l}\text { 25-m Crosslinked methyl } \\
\quad \text { silicone } \\
0.22-\mathrm{mm} \text { i.d. } \\
0.33-\mu \mathrm{m} \text { film thickness } \\
\text { Hewlett-Packard }\end{array}$} \\
\hline
\end{tabular}

Site 644-Voring Basin

ODP Site 644 , located in the Vøring Basin close to the inner continental slope, overlies subsided continental crust at 1227 mbsl. Drilling at this site recovered $250 \mathrm{~m}$ of core. Organic carbon content ranges from $0.4 \%$ to $1.0 \%$. No trend with depth is apparent (Fig. 2, Table 3). Typing by Rock-Eval suggests the presence of predominantly immature organic matter of terrestrial origin (Kvenvolden and McDonald this volume). EOM ranges from $12 \mathrm{ppm}$ to $59 \mathrm{ppm}$ and averages $27 \mathrm{ppm}(\mathrm{n}=15$, Fig. 2, Table 3). UCM concentrations range from 9 to 43 ppm (Fig. 2). Total n-alkane concentrations range from $825 \mathrm{ppb}$ to $3,214 \mathrm{ppb}$ (Fig. 4, Table 3). The CPI varies from 1.9 to 3.5 and pristane/ phytane ratios vary from 0.5 to 4.3 . Individual alkane concentrations were two- to three- fold higher at Site 644 than at Sites 642 and 643 and often exceed 50 ppb (Fig. 3). Total PAH concentrations range from $53 \mathrm{ppb}$ to $820 \mathrm{ppb}$ (Table 3 ). In general, PAH with three or more rings are significantly higher at Site 644 than at Sites 642 and 643 (Fig. 5 and 6). All sections contain a complex mixture of aromatic hydrocarbons indicative of mature petroleum-related compounds, but there is no apparent trend with depth (Figs. 5 and 6). The same ice-rafted source of hydrocarbons is suggested at Site 644 as at the other sites. At Site 644 the EOM, UCM, total alkanes, and terrestrially sourced hydrocarbons all covary with subsurface maxima at approximately 50,150 , and $200 \mathrm{~m}$ (Figs. 4 and 5). The aromatic hydrocarbon distributions also exhibit similar trends (Figs. 5 and 6). This covariation suggests a common source for both aliphatic and aromatic hydrocarbons that is closely associated with terrestrially derived materials, confirming the proposed recycled nature of the organic matter at these sites. The higher levels of hydrocarbons at Site 644 may be the result of (1) more organic material being ice-rafted to this site, (2) the original source material being enriched in hydrocarbons as compared to that which was the source of organic matter at the other two sites, and/or (3) the terrestrial input being less diluted with marine organic or inorganic material.

\section{CONCLUSIONS}

From recent investigations, it is well established that the major aspects of sediment distribution and morphology in the Vøring Plateau region are controlled by slumping and mass wasting which have occurred despite morphologically shallow gradients over many margin sediments. High sedimentation rates and li- 

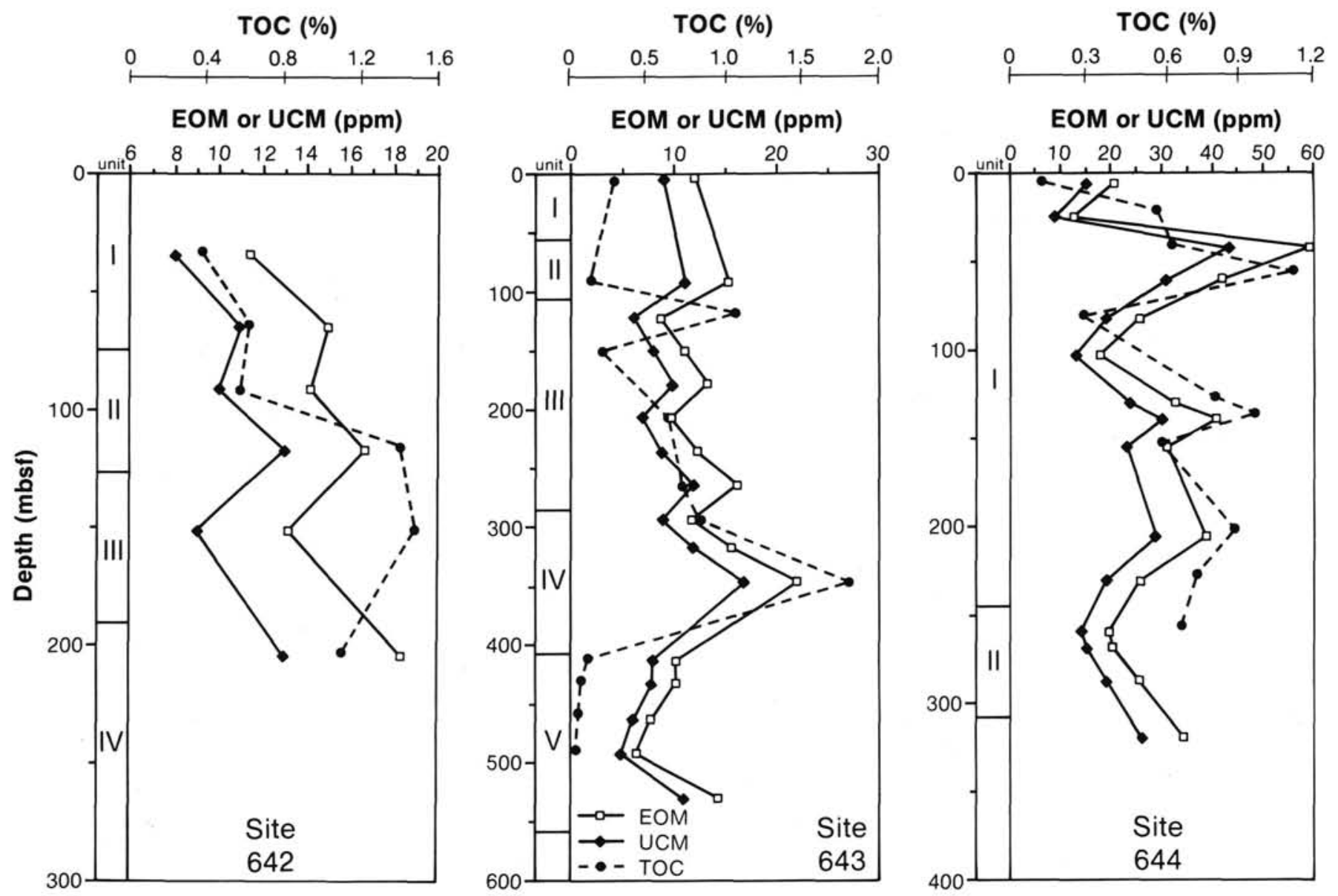

Figure 2. Variations in total organic carbon, extractable organic matter content, and unresolved complex mixture concentrations with depth at ODP Leg 104 sites.

Table 3. Summary of bulk organic matter and hydrocarbon parameters at Vóring Plateau, ODP Leg 104 sites.

\begin{tabular}{lccc}
\hline $\begin{array}{c}\text { Site } \\
\text { Parameter }\end{array}$ & 642 & 643 & 644 \\
\hline TOC (\%) & $0.9^{\mathrm{b}}$ & 0.5 & 0.7 \\
& $(0.3-1.5)^{\mathrm{c}}$ & $(<0.1-1.8)$ & $(0.4-1.0)$ \\
EOM (ppm) & 12 & 11 & 27 \\
& $(11-18)$ & $(6-22)$ & $(12-59)$ \\
UCM (ppm) & 11 & 10 & 22 \\
& $(8-13)$ & $(5-17)$ & $(9-43)$ \\
AH (ppb) & 1,013 & 542 & 1,454 \\
& $(239-1,478)$ & $(176-1,196)$ & $(825-3,214)$ \\
PAH (ppb) & 55 & 37 & 196 \\
& $(24-126)$ & $(6-95)$ & $(53-820)$ \\
CPI & 3.7 & 3.3 & 2.7 \\
& $(2.4-7.6)$ & $(1.0-5.3)$ & $(1.9-3.5)$ \\
Pristane/Phytane & 1.1 & 1.6 & 1.8 \\
Ratio & $(0.1-2.0)$ & $(0.6-3.9)$ & $(0.5-4.3)$ \\
\hline
\end{tabular}

a TOC-Total organic carbon; EOM-extractable organic matter; UCM-unresolved complex misture; $\mathrm{AH}-$ total aliphatic hydrocarbons (GC/FID); PAH-total aromatic hydrocarbons (GC/MS); CPI-carbon preference index.

$\mathrm{b}$ Average value.

${ }^{\mathrm{c}}$ Range in values.

thology probably play key roles in the process (Eldholm, Thiede, Taylor, et al., 1987). At Sites 642, 643, and 644, aliphatic hydrocarbons, aromatic hydrocarbons, the unresolved complex mixture, and extractable organic matter concentrations are low and exhibit no relationship to sub-bottom depth. These distributions are most likely caused by the episodic nature of and variations in organic matter inputs. Slumping and mass wasting would also tend to redistribute the organic matter after deposition-producing erratic distributions (Kennicutt et al., 1987a). During the early Pliocene and Pleistocene, interglacial conditions prevailed and the majority of sediment transport was off of the continental shelf into the deeper water sites (Eldholm, Thiede, Taylor, et al., 1987).

Morris (1976) analyzed sediment from Site 341 (DSDP Leg 38) which is located near Site 644 of this report (Fig. 1). He determined that all of the sections sampled contained petroleumlike compounds, and that their concentrations increased with depth. He suggested that petroleum had migrated from a deep source upward into these shallow, immature sediments. Hydrocarbon analyses at all three sites from this study also suggest the presence of mature hydrocarbons. This conclusion is based on the detection of a complex mixture of alkanes, naphthalenes, phenanthrenes, and other high molecular weight aromatic compounds of a mature nature. In contrast to the Morris (1976) study, no regular trends with depth were observed, contradicting an upward migratory source. Yet the presence of mature hydrocarbons in immature sediments needs explanation. Hydrocarbons that are present, other than those related to petroleum, are predominantly of terrestrial origin i.e., plant biowaxes with 23 to 31 carbons (particularly the odd-number alkanes). The most probable source of hydrocarbons and organic matter at these sites is ice-rafted debris. This interpretation is suggested by the sporadic distribution of the hydrocarbons, the covariation in many organic matter characteristics, and the aforementioned lack of increasing amounts of hydrocarbons with increasing depth. The abundance of reworked Cretaceous and early Tertiary nannofossils present at these sites (Donnally, this volume) confirms that the recycling of mature, older sediments from the 

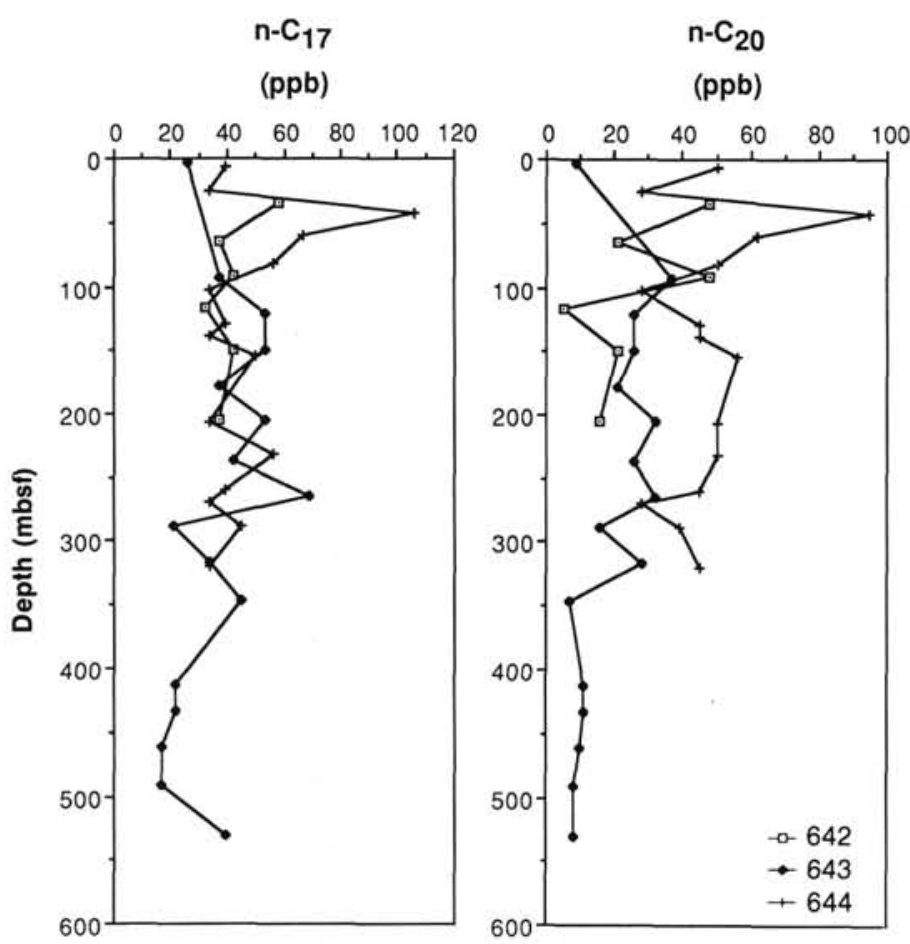

$n-C_{25}$

(ppb)

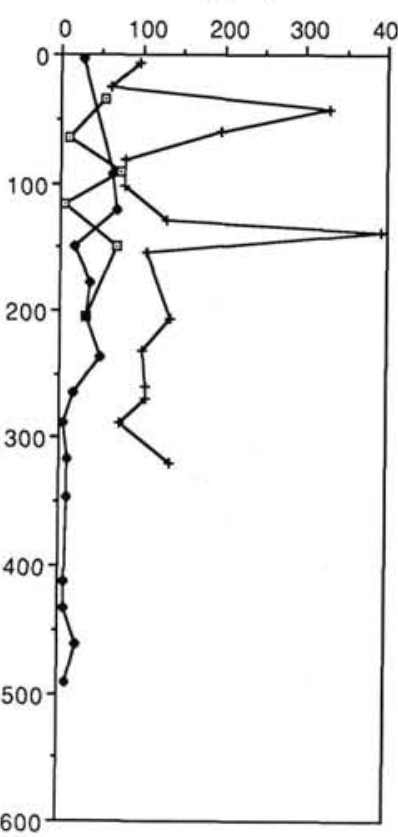

$\mathrm{n}-\mathrm{C}_{31}$

(ppb)

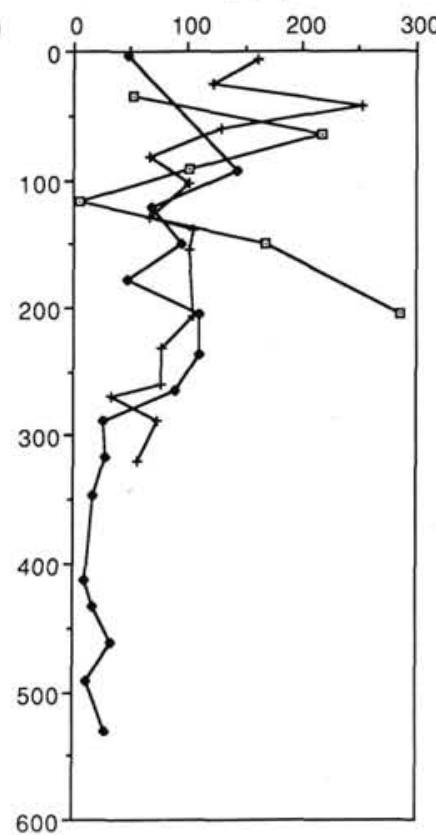

Figure 3. Variations in selected individual normal alkane concentrations with depth at ODP Leg 104 sites.

adjacent exposed continent has extensively influenced sedimentary organic matter on the Vøring Plateau.

\section{ACKNOWLEDGMENTS}

Support for this project was provided by the United States Scientific Advisory Committee (USSAC). This article benefited from the reviews of Patrick L. Parker and Roger Burke.

\section{REFERENCES}

Eldholm, O., Thiede, J., Taylor, E., 1987. Proc. ODP, Init. Repts., 104: College Station, TX (Ocean Drilling Program).

Erdman, J. G., and Schorno, K. S., 1976. Geochemistry of carbon, DSDP Leg 38. In Talwani, M., Udintsev, G., et al., Init. Repts. DSDP, 38: Washington (U.S. Govt. Printing Office), 791-799.

Hood, A., Castaño, J. R., and Kendrick, J. W., 1976. Petroleum-generating potential and thermal history of DSDP Leg 38 sediments. In Talwani, M., Udintsev, G., et al., Init. Repts. DSDP, 38: Washington (U.S. Govt. Printing Office), 801-803.
Kennicutt, II, M. C., Denoux, G. J., Brooks, J. M., and Sandberg, W. A., 1987a. Hydrocarbons in Mississippi fan and intraslope basin sediments. Geochim. Cosmochim. Acta, 51: 1457-1466.

Kennicutt, II, M. C., Barker, C., Brooks, J. M., DeFreitas, D. A., and Zhu, G. H., 1987b. Selected organic matter source indicators in the Orinoco, Nile, and Changiiang Deltas. Org. Geochem., 11: 41-51.

MacLeod W. D., Jr., Brown, D. W., Friedman, A. J., Burrows, D. G., Maynes, O., Pearce, R. W., Wigren, C. A., and Bogar, R. G., 1985. Standard analytical procedures of the NOAA analytical facility, 1985-1986. Extractable toxic organic compounds, 2nd edition. NOAA Tech. Memo. NMFS F/NWC-92: Washington (National Marine Fisheries Service, NOAA).

Morris, D. A., 1976. Organic diagenesis of Miocene sediments from Site 341, Vøring Plateau, Norway. In Talwani, M., Udintsev, G., et al., Init. Repts. DSDP, 38: Washington (U.S. Govt. Printing Office), 809-814.

Date of initial receipt: 15 June 1987

Date of acceptance: 16 December 1987

Ms 104B:123 

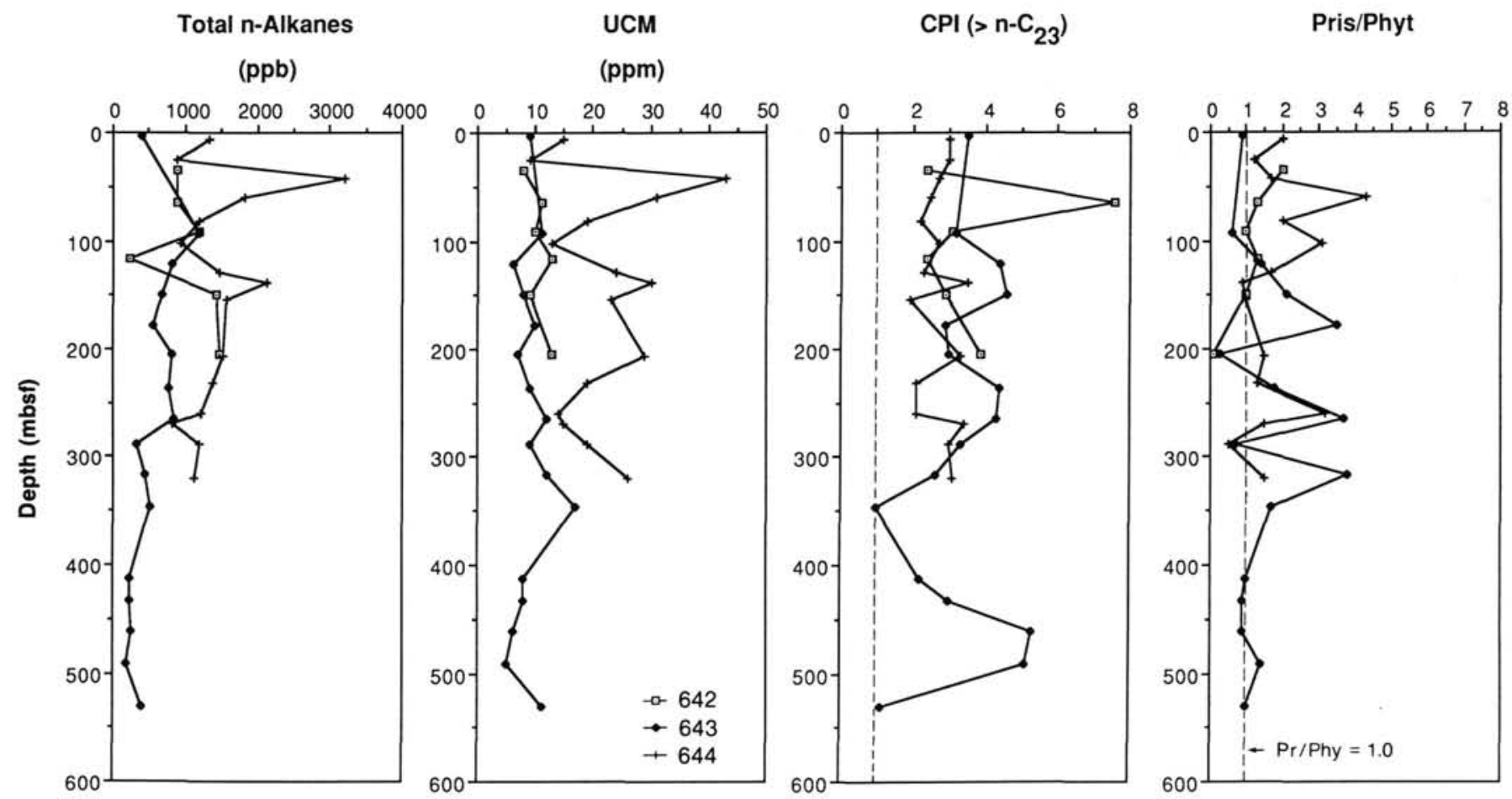

Figure 4. Variations in total n-alkane concentrations $C_{15}$ to $C_{32}$, and in selected aliphatic hydrocarbon ratios, with depth at ODP Leg 104 sites.
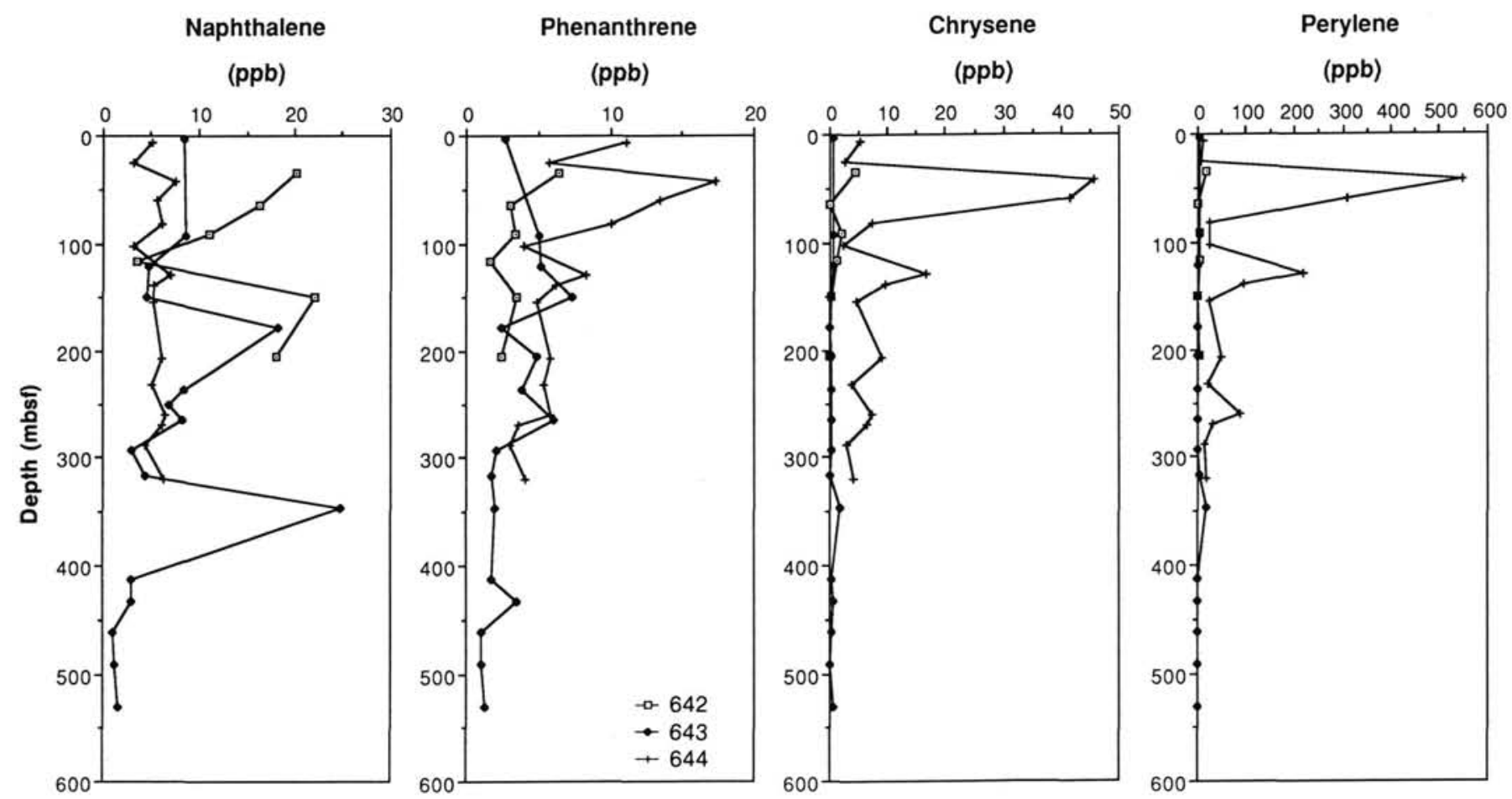

Figure 5. Variations in selected aromatic hydrocarbon concentrations with depth at ODP Leg 104 sites. 


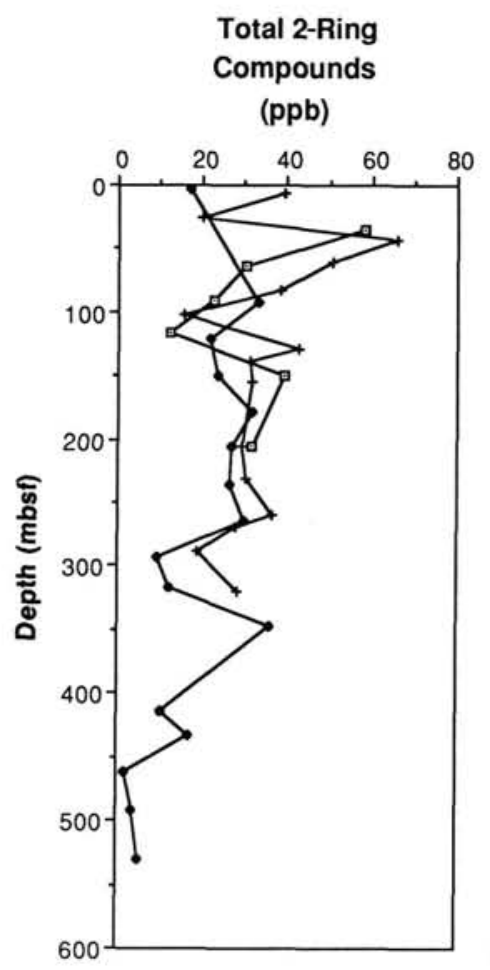

\section{Total 3-Ring \\ Compounds}

(ppb)
Total 4-Ring

Compounds

(ppb)
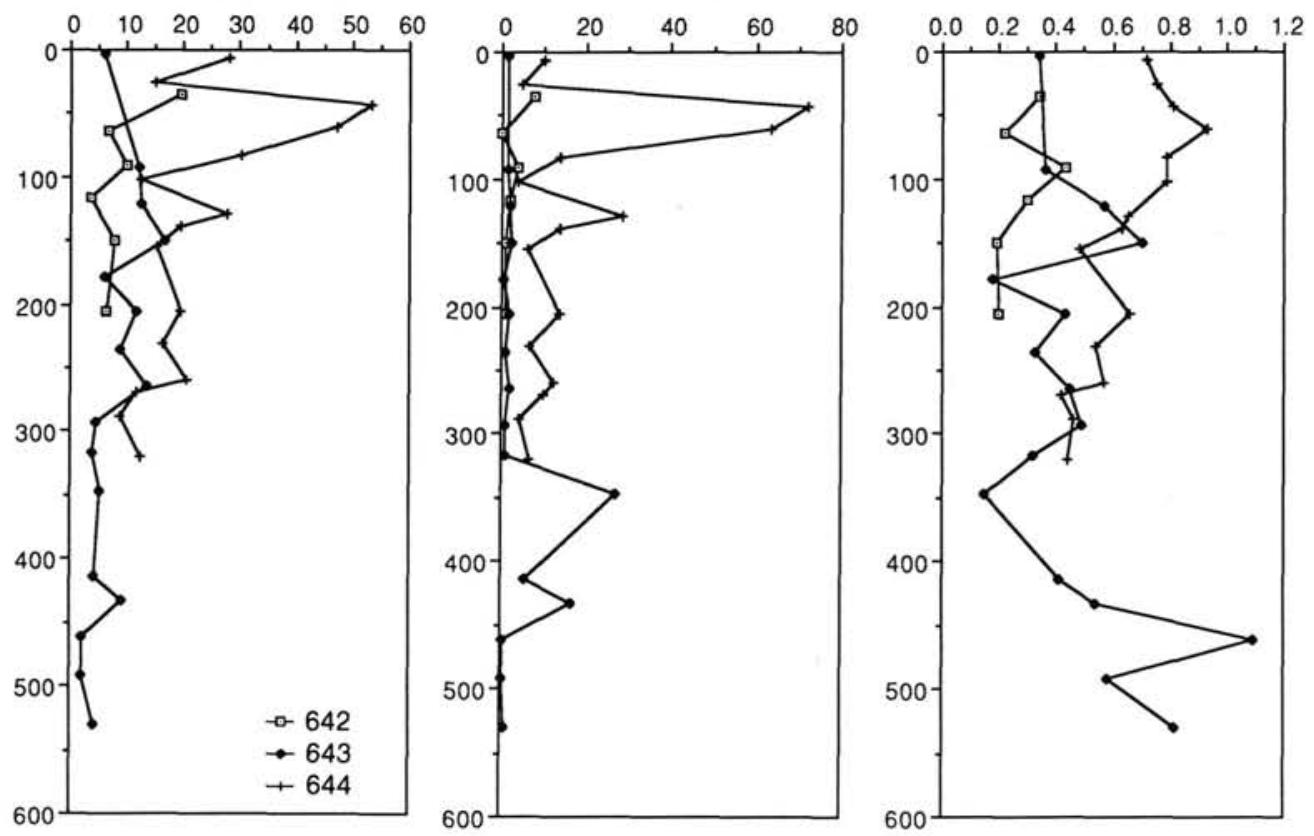

Figure 6. Variations in selected suites of aromatic hydrocarbons and the ratio of phenanthrenes to naphthalenes with depth at ODP Leg 104 sites (2ring $=$ naphthalene + methyl naphthalenes + dimethylnaphthalenes + biphenyl; 3-ring $=$ phenanthrene + anthracene + methyl phenanthrenes; $4-$ ring $=$ benz(a)anthracene + chrysene + pyrene; 5 -ring $=$ benzo(e)pyrene + benzo(a)pyrene + perylene + dibenzanthracene $)$. 
APPENDIX

Hydrocarbon Data

\begin{tabular}{|c|c|c|c|c|c|c|c|c|c|c|c|c|c|c|}
\hline \multirow[b]{2}{*}{ Site } & \multicolumn{14}{|c|}{ Normal alkane concentrations } \\
\hline & $\begin{array}{l}\text { Depth } \\
\text { (mbsf) }\end{array}$ & $\begin{array}{l}\text { TOC } \\
(\%)\end{array}$ & $\begin{array}{l}\text { EOM } \\
\text { (ppm) }\end{array}$ & $\begin{array}{l}\text { TOT } \\
\text { UCM } \\
\text { (ppm) }\end{array}$ & $\begin{array}{l}\mathrm{n}-\mathrm{C}_{11} \\
(\mathrm{ppb})\end{array}$ & $\begin{array}{l}\mathrm{n}-\mathrm{C}_{12} \\
(\mathrm{ppb})\end{array}$ & $\begin{array}{l}\mathrm{n}-\mathrm{C}_{13} \\
(\mathrm{ppb})\end{array}$ & $\begin{array}{l}\mathrm{n}-\mathrm{C}_{14} \\
(\mathrm{ppb})\end{array}$ & $\begin{array}{l}\mathrm{n}-\mathrm{C}_{15} \\
(\mathrm{ppb})\end{array}$ & $\begin{array}{l}\mathrm{n}-\mathrm{C}_{16} \\
(\mathrm{ppb})\end{array}$ & $\begin{array}{l}\mathrm{n}-\mathrm{C}_{17} \\
\text { (ppb) }\end{array}$ & $\begin{array}{l}\text { Prist } \\
\text { (ppb) }\end{array}$ & $\begin{array}{l}\mathrm{n}-\mathrm{C}_{18} \\
\text { (ppb) }\end{array}$ & $\begin{array}{l}\text { Phyt } \\
\text { (ppb) }\end{array}$ \\
\hline $642 B$ & 34.3 & 0.3 & 11 & 8 & 11 & 21 & 26 & 53 & 64 & 58 & 58 & 42 & 58 & 21 \\
\hline 642D & 64.3 & 0.5 & 15 & 11 & 7 & 21 & 21 & 53 & 48 & 37 & 37 & 21 & 37 & 16 \\
\hline $642 B$ & 91.2 & 0.6 & 14 & 10 & 5 & 21 & 26 & 69 & 64 & 53 & 42 & 16 & 85 & 16 \\
\hline 642D & 116.8 & 1.4 & 17 & 13 & 5 & 6 & 9 & 26 & 26 & 26 & 32 & 7 & 37 & 6 \\
\hline 642B & 151.3 & 1.5 & 13 & 9 & 5 & 21 & 21 & 69 & 79 & 53 & 42 & 21 & 63 & 21 \\
\hline 642B & 205.3 & 1.2 & 18 & 13 & 8 & 26 & 21 & 53 & 48 & 37 & 37 & 3 & 37 & 21 \\
\hline $643 \mathrm{~A}$ & 3.2 & 0.3 & 12 & 9 & 16 & 16 & 12 & 32 & 26 & 21 & 26 & 10 & 16 & 12 \\
\hline $643 \mathrm{~A}$ & 92.3 & 0.1 & 15 & 11 & 16 & 26 & 26 & 69 & 64 & 53 & 37 & 16 & 69 & 26 \\
\hline $643 \mathrm{~A}$ & 121.1 & 1.1 & 9 & 6 & 6 & 14 & 14 & 42 & 53 & 48 & 53 & 21 & 42 & 15 \\
\hline $643 A$ & 149.6 & 0.2 & 11 & 8 & 10 & 21 & 21 & 58 & 58 & 48 & 53 & 16 & 42 & 7 \\
\hline $643 \mathrm{~A}$ & 178.1 & nd & 13 & 10 & 9 & 16 & 12 & 37 & 37 & 32 & 37 & 16 & 32 & 5 \\
\hline $643 \mathrm{~A}$ & 205.5 & 0.6 & 10 & 7 & 12 & 21 & 21 & 58 & 58 & 48 & 53 & 5 & 53 & 16 \\
\hline $643 A$ & 235.6 & 0.7 & 12 & 9 & 7 & 12 & 16 & 37 & 37 & 37 & 42 & 37 & 37 & 21 \\
\hline $643 \mathrm{~A}$ & 264.1 & 0.7 & 16 & 12 & 11 & 32 & 32 & 85 & 79 & 64 & 69 & 58 & 58 & 16 \\
\hline $643 \mathrm{~A}$ & 282.5 & 0.8 & 12 & 9 & 6 & 11 & 12 & 26 & 21 & 21 & 21 & 7 & 26 & 10 \\
\hline $643 \mathrm{~A}$ & 316.1 & 1.1 & 16 & 12 & 8 & 17 & 15 & 45 & 39 & 34 & 34 & 28 & 39 & 7 \\
\hline $643 \mathrm{~A}$ & 346.6 & 1.8 & 22 & 17 & 15 & 22 & 22 & 62 & 56 & 45 & 45 & 28 & 56 & 17 \\
\hline $643 \mathrm{~A}$ & 413.1 & 0.1 & 10 & 8 & 10 & 8 & 9 & 22 & 22 & 17 & 22 & 8 & 17 & 8 \\
\hline $643 A$ & 433.5 & 0.1 & 10 & 8 & 1 & 2 & 4 & 13 & 17 & 16 & 22 & 4 & 17 & 5 \\
\hline $643 \mathrm{~A}$ & 462.1 & 0.1 & 8 & 6 & 3 & 3 & 5 & 12 & 14 & 13 & 17 & 6 & 15 & 7 \\
\hline $643 \mathrm{~A}$ & 492.1 & 0.1 & 7 & 5 & 3 & 5 & 6 & 16 & 17 & 15 & 17 & 5 & 13 & 4 \\
\hline $643 \mathrm{~A}$ & 530.1 & 0.0 & 14 & 11 & 3 & 10 & 13 & 28 & 34 & 34 & 39 & 17 & 39 & 17 \\
\hline $644 \mathrm{~A}$ & 6.1 & 0.4 & 21 & 15 & 17 & 22 & 28 & 50 & 56 & 45 & 39 & 22 & 28 & 11 \\
\hline $644 \mathrm{~A}$ & 25.0 & 0.6 & 13 & 9 & 17 & 17 & 17 & 34 & 39 & 34 & 34 & 13 & 34 & 11 \\
\hline $644 \mathrm{~A}$ & 42.6 & 0.7 & 59 & 43 & 34 & 50 & 67 & 106 & 129 & 118 & 106 & 106 & 151 & 62 \\
\hline 644A & 60.0 & 1.0 & 42 & 31 & 22 & 34 & 39 & 67 & 78 & 73 & 67 & 73 & 78 & 17 \\
\hline $644 \mathrm{~A}$ & 82.0 & 0.5 & 26 & 19 & 34 & 45 & 45 & 78 & 73 & 67 & 56 & 34 & 62 & 17 \\
\hline $644 \mathrm{~A}$ & 102.5 & nd & 18 & 13 & 10 & 17 & 17 & 34 & 34 & 34 & 34 & 22 & 39 & 7 \\
\hline $644 \mathrm{~A}$ & 129.5 & 0.8 & 33 & 24 & 17 & 28 & 34 & 67 & 56 & 50 & 39 & 28 & 56 & 17 \\
\hline $644 \mathrm{~A}$ & 139.0 & 0.8 & 41 & 30 & 17 & 17 & 28 & 50 & 45 & 39 & 34 & 10 & 62 & 11 \\
\hline $644 \mathrm{~A}$ & 155.0 & 0.6 & 31 & 23 & 22 & 39 & 45 & 90 & 78 & 62 & 50 & 22 & 84 & 22 \\
\hline $644 \mathrm{~A}$ & 205.6 & 0.8 & 39 & 29 & 39 & 34 & 34 & 62 & 56 & 39 & 34 & 17 & 67 & 11 \\
\hline $644 \mathrm{~A}$ & 231.0 & 0.7 & 26 & 19 & 22 & 39 & 39 & 84 & 84 & 67 & 56 & 22 & 90 & 17 \\
\hline $644 \mathrm{~A}$ & 259.6 & 0.7 & 19 & 14 & 22 & 28 & 34 & 62 & 62 & 50 & 39 & 39 & 73 & 12 \\
\hline $644 \mathrm{~A}$ & 269.1 & nd & 20 & 15 & 17 & 22 & 22 & 50 & 45 & 39 & 34 & 13 & 45 & 9 \\
\hline $644 \mathrm{~A}$ & 288.1 & nd & 26 & 19 & 13 & 22 & 28 & 62 & 56 & 50 & 45 & 12 & 73 & 22 \\
\hline $644 \mathrm{~A}$ & 319.6 & nd & 34 & 26 & 22 & 34 & 34 & 78 & 73 & 50 & 34 & 17 & 56 & 11 \\
\hline
\end{tabular}

nd $=$ not determined. mbsf $=$ meters below seafloor. $\mathrm{tr}=$ trace $(<0.1 \mathrm{ppb})$.

\begin{tabular}{|c|c|c|c|c|c|c|c|c|c|c|c|c|c|c|c|}
\hline \multirow[b]{2}{*}{ Site } & \multicolumn{15}{|c|}{ PAH (ppb) } \\
\hline & $\begin{array}{l}\text { Depth } \\
\text { (mbsf) }\end{array}$ & $\underset{>\mathrm{n}-\mathrm{C}_{23}}{\mathrm{CPI}}$ & $\begin{array}{l}\text { Pris/ } \\
\text { phyt }\end{array}$ & Naph & $\begin{array}{l}\text { 2-methyl } \\
\text { naph }\end{array}$ & $\begin{array}{l}\text { 1-methyl } \\
\text { naph }\end{array}$ & Biphenyl & $\begin{array}{c}\text { Dimeth } 2,6 \\
\text { naph } \\
\# 1\end{array}$ & $\begin{array}{l}\text { Dimeth } \\
\text { naph } \\
\# 2\end{array}$ & $\begin{array}{l}\text { Dimeth } \\
\text { naph } \\
\# 3\end{array}$ & $\begin{array}{c}\text { Dimeth } \\
\text { naph } \\
\# 4\end{array}$ & $\begin{array}{c}\text { Dimeth } \\
\text { naph } \\
\# 5\end{array}$ & $\begin{array}{c}\text { Dimeth } \\
\text { naph } \\
\# 6\end{array}$ & $\begin{array}{c}\text { Dimeth } \\
\text { naph } \\
\# 7\end{array}$ & Acenap \\
\hline $642 B$ & 34.3 & 2.4 & 2.0 & 20.2 & 12.3 & 13.4 & 1.6 & 0.7 & 2.4 & tr & 4.0 & 2.1 & 2.4 & 0.8 & 0.2 \\
\hline $642 \mathrm{D}$ & 64.3 & 7.6 & 1.3 & 16.4 & 2.5 & 1.7 & 1.1 & 0.6 & 1.8 & 0.9 & 2.0 & 1.9 & 1.5 & 0.8 & tr \\
\hline $642 B$ & 91.2 & 3.1 & 1.0 & 11.0 & 2.6 & 2.2 & tr & 0.4 & 1.6 & 0.1 & 2.0 & 1.1 & 1.1 & 0.5 & tr \\
\hline 642D & 116.8 & 2.4 & 1.3 & 3.5 & 2.6 & 1.9 & 0.7 & 0.3 & 1.1 & 0.1 & 1.2 & 0.7 & 0.6 & 0.2 & 0.2 \\
\hline $642 B$ & 151.3 & 2.9 & 1.0 & 22.1 & 5.2 & 3.3 & 1.4 & 0.5 & 2.3 & tr & 2.4 & 1.5 & 1.4 & 0.6 & 0.2 \\
\hline $642 B$ & 205.3 & 3.9 & 0.1 & 18.0 & 3.4 & 2.2 & 1.1 & 0.5 & 2.1 & 0.7 & 1.7 & 1.3 & 1.5 & 0.3 & tr \\
\hline $643 \mathrm{~A}$ & 3.2 & 3.5 & 0.9 & 8.5 & 2.4 & 1.1 & 1.0 & 0.5 & 1.3 & 0.2 & 1.4 & 0.8 & 0.8 & 0.2 & tr \\
\hline $643 \mathrm{~A}$ & 92.3 & 3.2 & 0.6 & 8.6 & 9.2 & 4.4 & 2.1 & 0.5 & 2.9 & tr & 2.6 & 2.1 & 1.4 & 1.2 & 0.4 \\
\hline $643 \mathrm{~A}$ & 121.1 & 4.4 & 1.4 & 4.7 & 6.5 & 3.4 & 1.4 & 0.5 & 1.7 & tr & 1.7 & 1.7 & 1.3 & 0.4 & 0.4 \\
\hline $643 \mathrm{~A}$ & 149.6 & 4.6 & 2.1 & 4.6 & 4.2 & 2.8 & 2.2 & 0.8 & 3.2 & tr & 3.0 & 2.5 & 2.0 & 0.5 & 0.1 \\
\hline $643 \mathrm{~A}$ & 178.1 & 2.9 & 3.5 & 18.3 & 4.1 & 3.0 & tr & 0.3 & 1.6 & 0.2 & 1.7 & 1.3 & 0.9 & 0.4 & 0.4 \\
\hline $643 \mathrm{~A}$ & 205.5 & 3.0 & 0.3 & 6.8 & 5.7 & 3.2 & 1.6 & 0.7 & 3.0 & tr & 3.2 & 1.8 & 1.8 & 0.7 & 0.2 \\
\hline $643 \mathrm{~A}$ & 235.6 & 4.4 & 1.8 & 8.4 & 6.0 & 3.9 & 1.3 & 0.8 & 1.7 & $\mathrm{tr}$ & 2.0 & 1.6 & 1.4 & 0.9 & 0.2 \\
\hline $643 \mathrm{~A}$ & 264.1 & 4.3 & 3.7 & 8.3 & 6.3 & 3.7 & 2.1 & 0.7 & 2.9 & tr & 2.9 & 2.2 & 2.0 & 0.8 & 0.3 \\
\hline $643 \mathrm{~A}$ & 282.5 & 3.3 & 0.7 & 2.9 & 1.7 & 0.8 & 0.8 & 0.4 & 1.1 & 0.1 & 0.9 & 0.9 & 0.7 & 0.1 & 0.1 \\
\hline $643 \mathrm{~A}$ & 316.1 & 2.6 & 3.8 & 4.3 & 2.5 & 1.8 & 0.6 & 0.2 & 1.0 & tr & 0.9 & 0.9 & 0.5 & 0.2 & tr \\
\hline $643 \mathrm{~A}$ & 346.6 & 1.0 & 1.7 & 24,8 & 3.7 & 2.0 & 0.9 & 0.4 & 1.5 & $\mathrm{tr}$ & 1.4 & 1.0 & 0.9 & 0.3 & tr \\
\hline $643 \mathrm{~A}$ & 413.1 & 2.2 & 1.0 & 2.9 & 2.0 & 0.9 & 0.7 & 0.3 & 1.4 & tr & 1.0 & 0.5 & 0.7 & 0.5 & 0.2 \\
\hline $643 \mathrm{~A}$ & 433.5 & 3.0 & 0.9 & 2.9 & 4.5 & 3.6 & 0.6 & 0.1 & 1.6 & tr & 1.5 & 1.3 & 1.1 & 0.6 & 0.2 \\
\hline $643 \mathrm{~A}$ & 462.1 & 5.3 & 0.9 & 1.0 & 0.6 & 0.5 & 0.3 & $\mathrm{tr}$ & tr & tr & tr & tr & tr & tr & 0.1 \\
\hline $643 \mathrm{~A}$ & 492.1 & 5.1 & 1.4 & 1.2 & 1.0 & 0.4 & 0.4 & 0.1 & 0.4 & tr & 0.3 & 0.2 & 0.3 & 0.1 & 0.1 \\
\hline $643 \mathrm{~A}$ & 530.1 & 1.1 & 1.0 & 1.5 & 0.9 & 0.5 & 0.4 & 0.3 & 0.5 & tr & 0.7 & 0.5 & 0.3 & 0.2 & 0.2 \\
\hline $644 \mathrm{~A}$ & 6.1 & 3.0 & 2.0 & 5.1 & 10.3 & 7.2 & 4.5 & 0.8 & 4.2 & tr & 4.6 & 2.9 & 3.0 & 1.0 & 0.3 \\
\hline $644 \mathrm{~A}$ & 25.0 & 3.0 & 1.2 & 3.2 & 4.4 & 3.4 & 2.2 & 0.4 & 2.2 & tr & 2.3 & 1.7 & 1.8 & 0.6 & 0.3 \\
\hline $644 \mathrm{~A}$ & 42.6 & 2.7 & 1.7 & 7.6 & 16.6 & 11.9 & 5.0 & 2.3 & 6.7 & tr & 8.8 & 4.7 & 5.4 & 1.9 & 0.8 \\
\hline $644 \mathrm{~A}$ & 60.0 & 2.5 & 4.3 & 5.7 & 9.6 & 8.5 & 3.4 & 2.0 & 5.8 & $\mathrm{tr}$ & 8.0 & 4.3 & 5.1 & 1.8 & 0.9 \\
\hline $644 \mathrm{~A}$ & 82.0 & 2.2 & 2.0 & 6.2 & 9.0 & 0.1 & 8.3 & 1.5 & 5.1 & 0.2 & 6.8 & 3.7 & 4.2 & 1.4 & 0.2 \\
\hline $644 \mathrm{~A}$ & 102.5 & 2.7 & 3.1 & 3.2 & 3.0 & 3.1 & 1.1 & 0.1 & 1.2 & 0.1 & 1.9 & 1.1 & 1.3 & 0.4 & 0.2 \\
\hline $644 \mathrm{~A}$ & 129.5 & 2.3 & 1.7 & 7.0 & 8.0 & 8.4 & 2.4 & 1.3 & 3.7 & tr & 6.6 & 2.9 & 3.8 & 1.1 & 0.2 \\
\hline $644 \mathrm{~A}$ & 139.0 & 3.5 & 0.9 & 5.3 & 6.4 & 5.5 & 1.7 & 0.8 & 3.1 & $\mathrm{tr}$ & 4.4 & 2.4 & 2.5 & 0.9 & 0.2 \\
\hline $644 \mathrm{~A}$ & 155.0 & 1.9 & 1.0 & 5.3 & 5.7 & 5.2 & tr & 1.0 & 3.2 & tr & 4.3 & 3.0 & 3.1 & 0.8 & 0.5 \\
\hline 644A & 205.6 & 3.3 & 1.5 & 6.2 & 6.0 & 5.1 & 1.4 & 0.7 & 2.4 & tr & 4.0 & 1.9 & 2.3 & 0.6 & 0.4 \\
\hline $644 \mathrm{~A}$ & 231.0 & 2.1 & 1.3 & 5.1 & 7.6 & 7.5 & 1.1 & 0.2 & 2.0 & tr & 3.4 & 1.8 & 1.9 & 0.6 & 0.3 \\
\hline $644 \mathrm{~A}$ & 259.6 & 2.1 & 3.2 & 6.5 & 8.1 & 8.1 & 1.2 & 0.7 & 2.7 & tr & 4.5 & 2.3 & 2.5 & 1.0 & 0.4 \\
\hline $644 \mathrm{~A}$ & 269.1 & 3.4 & 1.5 & 6.2 & 5.2 & 5.1 & 1.4 & 0.6 & 2.1 & 0.1 & 3.9 & 2.0 & 2.1 & 0.8 & 0.4 \\
\hline $644 \mathrm{~A}$ & 288.1 & 3.0 & 0.5 & 4.3 & 4.3 & 3.5 & 0.9 & 0.4 & 1.5 & tr & 2.1 & 1.0 & 1.3 & 0.3 & 0.2 \\
\hline $644 \mathrm{~A}$ & 319.6 & 3.1 & 1.5 & 6.3 & 6.0 & 4.2 & 1.4 & 0.8 & 2.4 & tr & 3.9 & 2.2 & 2.1 & 0.7 & 0.4 \\
\hline
\end{tabular}

nd $=$ not determined. mbsf $=$ meters below seafloor. $\mathrm{tr}=$ trace $(<0.1 \mathrm{ppb})$. 
APPENDIX (continued).

\begin{tabular}{|c|c|c|c|c|c|c|c|c|c|c|c|c|c|c|}
\hline \multirow[b]{2}{*}{$\begin{array}{l}\mathrm{n}-\mathrm{C}_{19} \\
(\mathrm{ppb})\end{array}$} & \multicolumn{13}{|c|}{ Normal alkane concentrations } & \multirow{2}{*}{$\begin{array}{l}\text { Total } \\
\mathrm{n}-\mathrm{C}_{15} \text { to } \\
\mathrm{n}-\mathrm{C}_{32} \\
\text { (ppb) }\end{array}$} \\
\hline & $\begin{array}{l}\mathrm{n}-\mathrm{C}_{20} \\
(\mathrm{ppb})\end{array}$ & $\begin{array}{l}\mathrm{n}-\mathrm{C}_{21} \\
(\mathrm{ppb})\end{array}$ & $\begin{array}{l}\mathrm{n}-\mathrm{C}_{22} \\
(\mathrm{ppb})\end{array}$ & $\begin{array}{l}\mathrm{n}-\mathrm{C}_{23} \\
(\mathrm{ppb})\end{array}$ & $\begin{array}{l}\mathrm{n}-\mathrm{C}_{24} \\
(\mathrm{ppb})\end{array}$ & $\begin{array}{l}\mathrm{n}-\mathrm{C}_{25} \\
(\mathrm{ppb})\end{array}$ & $\begin{array}{l}\mathrm{n}-\mathrm{C}_{26} \\
(\mathrm{ppb})\end{array}$ & $\begin{array}{l}\mathrm{n}-\mathrm{C}_{27} \\
(\mathrm{ppb})\end{array}$ & $\begin{array}{l}\mathrm{n}-\mathrm{C}_{28} \\
(\mathrm{ppb})\end{array}$ & $\begin{array}{l}\mathrm{n}-\mathrm{C}_{29} \\
(\mathrm{ppb})\end{array}$ & $\begin{array}{l}\mathrm{n}-\mathrm{C}_{30} \\
(\mathrm{ppb})\end{array}$ & $\begin{array}{l}\mathrm{n}-\mathrm{C}_{31} \\
(\mathrm{ppb})\end{array}$ & $\begin{array}{l}\mathrm{n}-\mathrm{C}_{32} \\
(\mathrm{ppb})\end{array}$ & \\
\hline 53 & 48 & 13 & 42 & 53 & 37 & 53 & 32 & 74 & 32 & 69 & 21 & 53 & 3 & 884 \\
\hline 21 & 21 & 22 & 16 & 9 & 16 & 9 & 11 & 90 & 37 & 196 & C & 217 & 5 & 855 \\
\hline 48 & 48 & 8 & 21 & 48 & 37 & 74 & 42 & 180 & 64 & 207 & 48 & 101 & 3 & 1203 \\
\hline 32 & $<5$ & 8 & 8 & 6 & 10 & 5 & $<5$ & 16 & $<5$ & 10 & $<5$ & $<5$ & 3 & 239 \\
\hline 32 & 21 & 21 & 21 & 37 & 32 & 69 & 48 & 217 & 85 & 286 & 95 & 169 & 9 & 1423 \\
\hline 21 & 16 & 9 & 16 & 21 & 26 & 32 & 32 & 270 & 74 & 371 & 95 & 286 & 25 & 1478 \\
\hline 10 & 9 & 11 & 10 & 11 & 7 & 26 & 16 & 48 & 16 & 58 & 11 & 48 & 4 & 396 \\
\hline 42 & 37 & 21 & 26 & 42 & 26 & 64 & 42 & 154 & 64 & 212 & 42 & 143 & 15 & 1196 \\
\hline 32 & 26 & 26 & 26 & 21 & 12 & 69 & 11 & 95 & 32 & 138 & 21 & 69 & 14 & 825 \\
\hline 32 & 26 & 26 & 26 & 21 & 11 & 16 & 21 & 64 & 21 & 90 & C & 95 & 8 & 683 \\
\hline 32 & 21 & 21 & 21 & 21 & 12 & 37 & 21 & 58 & 21 & 69 & 21 & -48 & 4 & 565 \\
\hline 26 & 32 & 32 & 32 & 21 & 21 & 32 & 16 & 69 & 32 & III & 37 & 111 & 11 & 815 \\
\hline 26 & 26 & 26 & 26 & 21 & 21 & 48 & 16 & 74 & 26 & 122 & 21 & 111 & 1 & 779 \\
\hline 37 & 32 & 26 & 32 & 16 & 16 & 16 & 6 & 69 & 16 & 106 & 26 & 90 & 5 & 837 \\
\hline 16 & 16 & 8 & 10 & 8 & 8 & 5 & 3 & 37 & 13 & 48 & 12 & 26 & 2 & 319 \\
\hline 22 & 28 & 10 & 14 & 8 & 15 & 9 & 6 & 45 & 13 & 50 & 13 & 28 & 8 & 450 \\
\hline 34 & 7 & 17 & 28 & 17 & 28 & 11 & 11 & 39 & 22 & 11 & 22 & 17 & 11 & 522 \\
\hline 15 & 11 & 12 & 13 & 10 & 6 & 7 & 4 & 17 & 5 & 10 & 3 & 10 & 7 & 223 \\
\hline 13 & 11 & 10 & 11 & 10 & 5 & 8 & 5 & 17 & 7 & 22 & 7 & 17 & 1 & 225 \\
\hline 12 & 10 & 11 & 8 & 11 & 5 & 22 & 6 & 28 & 8 & 34 & 5 & 34 & 0 & 264 \\
\hline 8 & 8 & 10 & 8 & 7 & 3 & 10 & 2 & 17 & 3 & 15 & 3 & 12 & 0 & 176 \\
\hline 28 & 8 & 17 & 15 & 10 & 8 & C & 10 & 11 & 22 & 34 & 17 & 28 & 20 & 406 \\
\hline 50 & so & 39 & 39 & 84 & 45 & 95 & 78 & 196 & 62 & 179 & 34 & 162 & 17 & 1333 \\
\hline 28 & 28 & 22 & 28 & 50 & 34 & 62 & 50 & 118 & 39 & 118 & 28 & 123 & 7 & 900 \\
\hline 157 & 95 & 123 & 123 & 185 & 106 & 330 & 134 & 353 & 134 & 375 & 95 & 252 & 78 & 3214 \\
\hline 106 & 62 & 73 & 67 & 118 & 62 & 196 & 67 & 174 & 67 & 196 & 50 & 129 & 78 & 1831 \\
\hline 62 & 50 & 50 & 45 & 73 & 45 & 78 & 45 & 146 & 50 & 101 & 34 & 67 & 35 & 1188 \\
\hline 34 & 28 & 22 & 34 & 56 & 39 & 78 & 39 & 123 & 34 & 106 & 28 & 101 & 32 & 925 \\
\hline 84 & 45 & 56 & 67 & 118 & 62 & 129 & 62 & 207 & 67 & 168 & 45 & 67 & 62 & 1484 \\
\hline 73 & 45 & 34 & 50 & 118 & 62 & 392 & 39 & 515 & 73 & 213 & 17 & 106 & 196 & 2132 \\
\hline 95 & 56 & 45 & 45 & 90 & 50 & 106 & 95 & 196 & 67 & 174 & 39 & 101 & 95 & 1574 \\
\hline 56 & 50 & 45 & 45 & 112 & 62 & 134 & 78 & 269 & 112 & 230 & 6 & 106 & 0 & 1529 \\
\hline 78 & so & 39 & 39 & 73 & 50 & 101 & 56 & 174 & 67 & 146 & 28 & 78 & 67 & 1383 \\
\hline 62 & 45 & 34 & 34 & 67 & 45 & 106 & 67 & 146 & 56 & 118 & 28 & 78 & 45 & 1205 \\
\hline 45 & 28 & 22 & 22 & 50 & 28 & 106 & 28 & 134 & 28 & 78 & 11 & 34 & 25 & 825 \\
\hline 62 & 39 & 28 & 28 & 56 & 34 & 73 & 34 & 174 & 62 & 202 & 45 & 73 & 19 & 1184 \\
\hline 39 & 45 & 28 & 22 & 50 & 34 & 134 & 39 & 168 & 39 & 151 & 56 & 56 & 13 & 1116 \\
\hline
\end{tabular}

\begin{tabular}{|c|c|c|c|c|c|c|c|c|c|c|c|c|c|c|}
\hline \multirow[b]{2}{*}{ Fluorene } & \multirow[b]{2}{*}{ Phenan } & \multirow[b]{2}{*}{ Anthrac } & \multirow[b]{2}{*}{$\begin{array}{l}\text { 3-methyl } \\
\text { phenan }\end{array}$} & \multirow[b]{2}{*}{$\begin{array}{l}\text { 2-methyl } \\
\text { phenan }\end{array}$} & \multirow[b]{2}{*}{$\begin{array}{l}\text { 9-methyl } \\
\text { phenan }\end{array}$} & \multicolumn{3}{|c|}{$\mathrm{PAH}(\mathrm{ppb})$} & \multirow[b]{2}{*}{$\begin{array}{l}\text { Benz(a) } \\
\text { anthrac }\end{array}$} & \multirow[b]{2}{*}{ Chrysene } & \multirow[b]{2}{*}{$\begin{array}{c}\text { Benzo(a) } \\
\text { pyrene }\end{array}$} & \multirow[b]{2}{*}{$\begin{array}{c}\text { Benzo(a) } \\
\text { pyrene }\end{array}$} & \multirow[b]{2}{*}{ Perylene } & \multirow[b]{2}{*}{$\begin{array}{l}\text { Dibenz } \\
\text { anthrac }\end{array}$} \\
\hline & & & & & & $\begin{array}{l}\text { 1-methyl } \\
\text { phenan }\end{array}$ & Fluoranth & Pyrene & & & & & & \\
\hline 1.3 & 6.4 & 0.2 & 2.9 & 3.1 & 4.4 & 2.7 & 1.4 & 2.2 & 1.2 & 4.4 & 6.9 & 1.8 & 16.7 & 10.1 \\
\hline 0.8 & 3.0 & tr & 0.6 & 0.7 & 1.5 & 0.9 & tr & tr & tr & tr & tr & tr & $\mathrm{tr}$ & tr \\
\hline 0.8 & 3.4 & tr & 1.8 & 1.7 & 1.8 & 1.1 & 0.4 & 0.7 & 0.8 & 2.1 & 1.7 & tr & 4.1 & tr \\
\hline 0.4 & 1.6 & tr & 0.5 & 0.6 & 0.6 & 0.3 & 0.7 & 0.3 & 0.2 & 1.3 & 0.2 & 0.2 & 4.1 & 0.1 \\
\hline 1.0 & 3.5 & tr & 1.2 & 1.0 & 1.2 & 0.8 & 0.3 & 0.4 & tr & 0.4 & tr & tr & 1.4 & tr \\
\hline 1.0 & 2.4 & tr & 1.1 & 0.8 & 0.9 & 1.1 & tr & 1.0 & $\mathrm{tr}$ & tr & tr & tr & 4.3 & tr \\
\hline 0.6 & 2.7 & tr & 0.7 & 0.7 & 1.2 & 0.7 & 0.9 & 0.9 & $\mathrm{tr}$ & 0.5 & 1.0 & tr & 4.5 & tr \\
\hline 1.3 & 5.0 & 0.2 & 1.7 & 2.0 & 1.9 & 1.1 & 0.5 & 0.6 & 0.4 & 0.6 & 3.2 & tr & 4.9 & 1.0 \\
\hline 1.5 & 5.2 & 0.1 & 1.8 & 1.8 & 2.2 & 1.3 & 1.0 & 1.0 & 0.2 & 0.5 & 1.1 & 0.2 & 0.3 & tr \\
\hline 2.1 & 7.4 & 0.1 & 2.4 & 2.8 & 2.4 & 1.5 & 1.3 & 2.1 & 0.2 & 0.3 & 0.9 & tr & 0.9 & 0.1 \\
\hline 0.7 & 2.4 & tr & 0.8 & 1.2 & 1.0 & 0.5 & tr & 0.7 & tr & tr & tr & tr & tr & tr \\
\hline 1.5 & 4.9 & 0.3 & 1.6 & 1.7 & 1.9 & 1.2 & 0.8 & 1.4 & 0.2 & 0.2 & 0.8 & 0.2 & 0.9 & 0.1 \\
\hline 1.3 & 3.9 & 0.2 & 1.2 & 1.4 & 1.3 & 0.8 & 0.4 & 0.4 & tr & 0.4 & 0.2 & 0.2 & 0.6 & 0.3 \\
\hline 1.8 & 6.1 & 0.3 & 1.8 & 1.8 & 2.1 & 1.4 & 0.3 & 1.2 & 0.3 & 0.3 & 0.3 & 0.2 & 0.9 & 0.2 \\
\hline 0.7 & 2.1 & 0.1 & 0.6 & 0.7 & 0.7 & 0.5 & 0.4 & 0.7 & tr & 0.4 & 0.5 & 0.9 & 1.7 & 0.1 \\
\hline 0.4 & 1.7 & 0.2 & 0.6 & 0.6 & 0.5 & 0.3 & 0.2 & 0.8 & $\mathrm{tr}$ & tr & tr & tr & 1.9 & 0.4 \\
\hline 0.6 & 2.0 & tr & 1.0 & 0.9 & 0.8 & 0.6 & 0.7 & 23.7 & 1.5 & 1.9 & 2.1 & 4.9 & 17.6 & tr \\
\hline 0.5 & 1.8 & 0.1 & 0.6 & 0.6 & 0.6 & 0.5 & 0.5 & 5.0 & 0.5 & 0.3 & 1.2 & 1.1 & 1.4 & 0.3 \\
\hline 0.9 & 3.5 & 0.1 & 1.5 & 1.5 & 1.4 & 1.2 & 1.0 & 15.5 & 0.2 & 0.7 & 0.9 & 0.8 & 0.9 & tr \\
\hline 0.2 & 1.0 & ts & 0.3 & 0.4 & 0.3 & 0.3 & 0.1 & 0.1 & 0.1 & 0.2 & 0.1 & 0.1 & 0.3 & 0.1 \\
\hline 0.3 & 1.1 & $\mathrm{tr}$ & 0.3 & 0.4 & 0.3 & 0.2 & 0.1 & 0.3 & 0.1 & $\mathrm{tr}$ & 0.1 & tr & 0.1 & tr \\
\hline 0.4 & 1.3 & 0.1 & 0.8 & 0.9 & 0.8 & 0.5 & 0.1 & 0.2 & 0.3 & 0.6 & 0.1 & 0.1 & 0.3 & tr \\
\hline 2.3 & 11.1 & 0.1 & 4.2 & 5.4 & 4.2 & 3.2 & 2.5 & 3.3 & 1.3 & 5,4 & 5.2 & 0.5 & 11.3 & 0.4 \\
\hline 1.1 & 5.7 & 0.1 & 2.1 & 2.9 & 2.4 & 1.8 & 1.0 & 1.3 & 0.7 & 2.7 & 2.6 & 0.7 & 6.9 & 0.2 \\
\hline 4.5 & 17.3 & 0.7 & 8.6 & 9.0 & 10.1 & 7.5 & 9.8 & 17.7 & 8.8 & 45.6 & 33.7 & 24.3 & 549.0 & 0.8 \\
\hline 3.8 & 13.4 & 0.4 & 8.1 & 7.7 & 10.8 & 6.9 & 8.1 & 15.1 & 7.0 & 41.4 & 26.1 & 14.3 & 308.2 & 2.4 \\
\hline 3.1 & 10.0 & 0.2 & 4.8 & 5.5 & 5.7 & 4.0 & 3.2 & 4.8 & 1.7 & 7.2 & 9.3 & 1.8 & 26.3 & 0.7 \\
\hline 1.0 & 4.0 & tr & 2.0 & 2.2 & 2.4 & 1.7 & 1.0 & 1.3 & 0.1 & 2.2 & 2.5 & 0.8 & 25.9 & 0.4 \\
\hline 3.2 & 8.3 & 0.3 & 4.2 & 4.6 & 6.3 & 3.9 & 4.2 & 6.6 & 5.1 & 16.7 & 23.3 & 14.0 & 216.7 & 3.8 \\
\hline 2.0 & 6.2 & tr & 3.3 & 3.5 & 3.8 & 2.7 & 2.1 & 2.6 & 1.4 & 9.7 & 8.4 & 1.8 & 93.5 & 0.2 \\
\hline 1.9 & 4.9 & 0.1 & 2.6 & 2.8 & 2.9 & 2.0 & 1.5 & 0.6 & 0.9 & 4.8 & 4.9 & 1.0 & 24.5 & 1.0 \\
\hline 1.9 & 5.9 & 0.1 & 3.4 & 3.6 & 3.8 & 2.7 & 2,3 & 3.1 & 1.5 & 9.0 & 8.2 & 0.7 & 49.8 & 0.9 \\
\hline 1.8 & 5.4 & 0.1 & 2.6 & 2.8 & 3.3 & 2.2 & 1.5 & 2.2 & 0.7 & 3.8 & 4.7 & 0.3 & 19.5 & 0.3 \\
\hline 2.2 & 5.8 & 0.2 & 3.5 & 3.9 & 4.3 & 3.0 & 2.1 & 3.8 & 1.2 & 7.4 & 9.6 & 1.7 & 88.6 & 0.5 \\
\hline 1.4 & 3.6 & 0.1 & 1.9 & 2.0 & 2.6 & 1.6 & 1.5 & 2.6 & 1.2 & 6.3 & 7.2 & 1.4 & 33.2 & 0.3 \\
\hline 1.1 & 3.0 & tr & 1.3 & 1.5 & 1.7 & 1.2 & 0.7 & 1.0 & 0.4 & 2.9 & 3.4 & 0.9 & 14.8 & tr \\
\hline 1.9 & 4.1 & tr & 2.2 & 2.1 & 2.5 & 1.7 & 1.2 & 1.8 & 0.7 & 4.1 & 3.3 & 0.5 & 1.3 & tr \\
\hline
\end{tabular}

